\title{
ZAGADNIENIA PROJEKTOWANIA REGENERATYWNEGO W MIEŚCIE
}

\author{
Kinga Zinowiec-Cieplik ${ }^{\bowtie}$ \\ Wydział Architektury, Politechnika Warszawska
}

\begin{abstract}
STRESZCZENIE
Kształtowanie terenów otwartych w strukturze funkcjonalno-przestrzennej miasta jest przedmiotem badań i analiz na potrzeby określenia czynników wpływających na komfort życia i parametry środowiska w mieście oraz formułowania wniosków dla planowania zagospodarowania przestrzennego i krajobrazu miasta. Wskazywane są obszary problemowe dotyczące przekształcania terenów otwartych w mieście. Możliwość regeneracji ekosystemu miejskiego, poprawy parametrów środowiska miejskiego oraz integracji społecznej wiążą się z nowoczesnym projektowaniem struktury funkcjonalno-przestrzennej tworzącej nierozerwalną całość z systemem przyrodniczym w ramach m.in. zielonej i błękitnej infrastruktury. Analiza współczesnych modeli kształtowania terenów otwartych w mieście wskazuje na przykłady wdrażania zasad projektowania regeneratywnego. Charakterystyka projektowania terenów otwartych prowadzi do opracowania wytycznych na potrzeby nowych standardów kształtowania struktury funkcjonalno-przestrzennej powiązanej z systemem przyrodniczym miasta. Współczesne planowanie przestrzenne powinno uwzględniać regeneratywne parametry funkcjonalne, jakościowe i wydajność zieleni optymalizując sposób realizacji w powiązaniu z usługami dla integracji społeczności lokalnej.
\end{abstract}

Słowa kluczowe: tereny otwarte, projektowanie regeneratywne, struktura funkcjonalno-przestrzenna miasta, system zieleni miejskiej, zielona i błękitna infrastruktura

\section{WSTĘP}

Raporty ośrodków badawczych oraz Światowej Komisji Środowiska i Rozwoju ONZ (World Commission on Environment and Development - WCED), wskazują na prognozowany wzrost liczby ludności zamieszkującej tereny zurbanizowane (Revision of the World Urbanization Prospects, 2018).

Zasadne jest zatem podejmowanie badań i opracowań dotyczących sposobu kształtowania struktury funkcjonalno-przestrzennej i parametrów środowiska terenów zurbanizowanych w odniesieniu do światowych tendencji projektowych związanych z wdrażaniem rozwiązań prośrodowiskowych. Analiza literatury przedmiotu oraz strategii rozwoju miast wdrażających idee Eco City (Roseland, 1997;
Rapoport i Vernay, 2011), Smart City (Bibri i Krogstie, 2020) i Green City (Joss, 2011; Joss, Tomozeiu, i Cowley, 2011; Green City Programme, 2016) wskazuje na konieczność realizacji zielonej i błękitnej infrastruktury stanowiących powierzchnie biologicznie czynne na potrzeby realizacji różnych zadań ekosystemowych w systemie przyrodniczym miasta. Zieleń i woda w mieście mogą pełnić różnorodne funkcje w kształtowaniu środowiska miejskiego i znacząco wpływają na komfort życia oraz budowanie tożsamości miejsca (Ryńska, 2012; Świątek, 2016). Regeneratwność w urbanistyce jest rozwinięciem i integracją idei Eco Cities, Smart Cities i Green Cities wprowadzających nowoczesne prośrodowiskowe technologie i rozwiązania na rzecz kształtowania struktury funkcjonalno-przestrzennej 
terenów zurbanizowanych w powiązaniu z systemem przyrodniczym miasta. W niniejszej pracy wskazywane zostały obszary problemowe dotyczące kształtowania terenów otwartych i wytyczne w celu wielokryterialnego przekształcania struktury miasta.

Celem artykułu jest określenie prezentowanie wniosków $\mathrm{z}$ teorii projektowania regeneratywnego $\mathrm{z}$ odniesieniem do realizacji wdrażających integrację usług dla społeczności lokalnej z usługami ekosystemowymi powierzchni biologicznie czynnych systemu przyrodniczego miasta.

W pracy postawiono hipoteze $\mathrm{w}$ następującym brzmieniu: idea regeneratywnego kształtowania terenów otwartych w mieście wymaga integracji usług dla społeczności lokalnej z usługami ekosystemowymi biologicznie czynnej zielonej i błękitnej infrastruktury, w strukturze funkcjonalno-przestrzennej i systemie przyrodniczym miasta.

Badanie przeprowadzone zostało poprzez analizę zagadnień problemowych, dotyczących współczesnych idei kształtowania miasta jako podstawy do rozwoju projektowania regeneratywnego oraz realizacji terenów otwartych $\mathrm{w}$ mieście, w tym zielonych dachów jako powierzchni biologicznie czynnych z usługami ekosystemowymi oraz usługami dla społeczności lokalnej.

Wyróżniono trzy podstawowe zagadnienia badawcze prezentowane $\mathrm{w}$ pracy:

1. Problematyka teorii projektowania regeneratywnego w mieście jako rozwinięcie współczesnych idei rozwoju miasta.

2. Problematyka kształtowania terenów otwartych w mieście.

3. Projektowanie regeneratywne w kształtowaniu współczesnych miast.

Praca obejmuje analizę literatury, zapisów legislacyjnych i planistycznych oraz wielokryterialne porównawcze analizy realizacji inwestycji wyselekcjonowanych stosownie do zagadnienia problemowego.

W niniejszej pracy opisywane jest zagadnienie zagospodarowania terenów otwartych w kontekście prognozowanych kierunków rozwoju współczesnych nurtów prośrodowiskowego kształtowania miasta.

\section{PROBLEMATYKA TEORII PROJEKTOWANIA REGENERATYWNEGO W MIEŚCIE JAKO ROZWINIĘCIE WSPÓŁCZESNYCH IDEI ROZWOJU MIASTA}

Pierwszy podręcznik projektowania regeneratywnego (Regenerative Design for Sustainable Development, 1994) został opublikowany w 1994 roku. Autor podręcznika J.T. Lyle wskazywał zastąpienie linearnych procesów cyrkularnymi procesami przepływu energii i materii (Lyle, 1994). Projektowanie regeneratywne prowadzić miało do powstawania systemów przestrzennych zapewniających odnawialność, czyli regenerację zużytych zasobów w procesie budowy i szeroko rozumianej konsumpcji (Mang i Reed, 2012). Istota problemu polega na projektowaniu struktury funkcjonalno-przestrzennej i środowiska umożliwiające regenerację ekosystemową oraz liczne procesy wpływające na ich funkcjonowanie. Podejście to wskazuje na konieczność wprowadzania rozwiązań systemowych wykraczających poza problematykę gospodarowania zasobami i możliwości odtwarzania zasobów. Innowacja polega na wskazaniu projektowania procesów użytkowych i uwarunkowań dla ich realizacji, w odniesieniu do systemu przyrodniczego. Takie założenia projektowe stanowią podstawę modelu zintegrowanego projektowania realizowanego przez interdyscyplinarne zespoły architektów i architektów krajobrazu, biologów, ekologów, hydrologów i geologów, po specjalności rolnicze i ekonomiczne oraz infrastrukturalne. Rozwijając zasady integralnego projektowania regeneratywnego (DeKay, 2011) w procesie decyzyjnym, udział mają również przedstawiciele nauk społecznych (socjourbaniści, psycholodzy przestrzeni) oraz użytkownicy (tzw. projektowanie partycypacyjne). Regeneratywne projektowanie procesów związanych z funkcjonowaniem ekosystemów miejskich powinno odpowiadać na potrzeby użytkowe, produkcyjne i konsumpcyjne użytkowników, ale zakładając, że użytkownikami przestrzeni miejskiej nie są tylko ludzie. Postulat bioróżnorodności i efektywności powierzchni biologicznie czynnych warunkuje możliwość regeneracji i właściwego funkcjonowania systemu przyrodniczego w mieście, a tym samym stanowi o komforcie 
życia w mieście. Projektowanie regeneratywne stanowi podstawę do wielokryterialnego kształtowania parametrów środowiska zamieszkania i możliwości ich regulacji, czyli zarządzania w strukturze funkcjonalno-przestrzennej miasta, co stanowi rozwinięcie idei Smart City (Cohen, 2015; McLaren i Agyeman, 2015).

Projektowanie regeneratywne rozwija zagadnienie zarządzania w odniesieniu do kształtowania parametrów środowiska i efektywności przyrodniczej, związanej z koniecznością reakcji na zmiany klimatyczne oraz jakościowe środowiska i krajobrazu miejskiego. Jest to rozwinięciem idei Eco City, definiowanej w 1987 roku jako miejski system środowiskowy, w którym wkład - zasobów oraz produkcji - odpadów jest zminimalizowany (Rapoport i Vernay, 2011). Pod koniec XX wieku sformułowane zostały kryteria modelowego Eco City (Roseland, 1997). Wskazywano, że miasto powinno być kształtowane na postawie samowystarczalnej gospodarki i powinno korzystać z lokalnych zasobów, zakładając neutralną pod względem emisji dwutlenku węgla produkcję energii ze źródeł odnawialnych i wydajny system transportu publicznego. Według założeń ideowych Eco City to nowoczesne miasto (Bibri i Krogstie, 2020), w którym zrównoważone sa działania na rzecz uwarunkowań środowiskowych, społecznych, przestrzennych, oraz ekonomicznych. Realizacja zielonej i błękitnej infrastruktury oraz wprowadzanie powierzchni biologicznie czynnych w intensywnej zabudowie miejskiej jest podstawą idei Green City.

W modelach rozwoju współczesnych miast wskazywane są działania w celu kształtowania zrównoważonego i trwałego środowiska miejskiego, w którym realizowane powinny być efektywne tereny biologicznie czynne zapewniające bioróżnorodność. Model regeneratywny rozwija te koncepcje, wskazując, że człowiek powinien czuć się częścią ekosystemu miasta i działać zgodnie z głębokim poszanowaniem i zrozumieniem jego procesów (Van der Ryn, 2013; Wahl, 2016). Zmiana intencji działań prowadzi do redefiniowania partycypacji w procesie decyzyjnym i użytkowym. Uwzględniając prawa i obowiązki współistnienia człowieka i natury, umożliwia się partycypację społeczną oraz przyrodniczą - ekosystemową party- cypację natury, zgodnie z „World Charter for Nature” (1982), „The Earth Charter” (2000), „Universal Declaration of Rights of Mather Earth” (2010), „Rights of Nature Tribunal" (2017). Projektowanie regeneratywne stanowi zatem zespolenie idei Smart City, Eco City i Green City ukierunkowane na zarządzanie i realizację struktury funkcjonalnej, usług dla społeczności lokalnej i terenów zieleni na potrzeby realizacji usług eko-systemowych i bioróżnorodności w systemie przyrodniczym miasta oraz zarządzania zasobami i przestrzenią miejską. Idea regeneratywnego rozwoju miasta determinuje realizację $\mathrm{w}$ intensywnej zabudowie powierzchni biologicznie czynnych na potrzeby mieszkańców i użytkowników przestrzeni miejskiej i terenów zieleni. Nie oznacza to jednak procesów renaturalizacji. Kształtowanie miasta w projektowaniu regeneratywnym priorytetowo traktuje świadome kształtowanie i przekształcanie struktury funkcjonalno-przestrzennej i wyposażenia miasta realizowanego dla zaspokojenia potrzeb ludzi, uwzględniając potrzeby środowiskowe i klimatyczne. Podstawowym zagadnieniem regeneratywnego projektowania jest programowanie i realizacja powierzchni biologicznie czynnych, terenów zieleni z usługami dla społeczności lokalnej. Realizowane sa jako niezabudowane otwarte przestrzenie publiczne (place, ulice, parki, skwery, bulwary, ogrody użytkowe i ozdobne), zieleń zintegrowana $\mathrm{z}$ zabudową (zielone dachy, ogrody wertykalne, farmy miejskie).

\section{PROBLEMATYKA KSZTALTOWANIA TERENÓW OTWARTYCH W MIEŚCIE}

W odniesieniu do założeń projektowania regeneratywnego tereny otwarte definiować należy jako przestrzenie publiczne (ogólnego dostępu) z programem użytkowym dla społeczności lokalnej oraz powierzchniami biologicznie czynnymi i infrastrukturą na potrzeby ekosystemowi i bioróżnorodności w mieście realizowanymi pomiędzy zabudową, oraz na budynkach w intensywnej zabudowie miejskiej. Powiązania terenów zieleni i przestrzeni publicznych z programem użytkowym są realizowane na ulicach i placach, bulwarach oraz w parkach (priorytetem ochrony), skwerach, ogrodach użytkowych i ozdobnych. 
Zieleń $\mathrm{w}$ mieście jest również wprowadzana na elewacjach $\mathrm{i}$ dachach oraz na terenach transportu publicznego (zielone torowiska). Prowadzone są prace nad powiązaniem terenów otwartych w mieście w układzie linearnym i centrycznym oraz uzupełnianie „szycie” systemów zieleni miejskiej. Jednakże publikowane badania przeważnie definiują tereny otwarte wyłącznie jako obszary niezabudowane i nieprzeznaczone pod inwestycje kubaturowe (Degórska, 2004).

W niniejszej pracy wskazano na redefiniowanie terenów otwartych, zwracając uwagę, że przy wykorzystaniu współczesnych technologii pozyskiwane są powierzchnie pod realizacje funkcji i programu terenów otwartych przeznaczanych do realizacji zielonej infrastruktury. Wskazuje się na fakt coraz powszechniejszego wykorzystywania dachów budynków, wprowadzania usług, zieleni i bioróżnorodności również na obiektach kubaturowych. Opisywane sa liczne korzyści realizacji zielonej infrastruktury integrowanej z zabudową, w tym poprawa izolacji budynków, ograniczanie zjawiska miejskiej wyspy ciepła, ograniczenie przed nadmiernym hałasem, retencja i zarządzanie wodami opadowymi (zatrzymywanie wody deszczowej i jej powtórne wykorzystanie). Zielone dachy w mieście mogą być realizowane jako typ ekstensywny i intensywny oraz układy mieszane tzw. półintensywne. Szacuje się, że dachy ekstensywne (pokryte matami rozchodnikowymi) mogą zatrzymywać ok. $60 \%$ deszczu w skali roku (Kwiecińska i Szałata, 2012, za Liu, 2012). Istotna jest również funkcja produkcyjna zieleni w mieście: produkcja tlenu, produkcja pożywienia oraz biomasy do wytworzenia energii i biopaliw.

Problematyka realizacji zielonych dachów jest istotna $\mathrm{w}$ modelu regeneratywnego kształtowania struktury funkcjonalno-przestrzennej i wyposażenia miasta. Z tego powodu, prezentowane są przykłady zielonych dachów jako terenów otwartych z powierzchnią biologicznie czynną i programem użytkowym dla społeczności lokalnej. W modelu regeneratywnym istotne są intensywne i półintensywne bioróżnorodne zielone dachy, na których można stosować zadrzewienia, krzewy, byliny, tworzyć alejki lub ustawiać ławki. Przypomina on więc skwer lub mały park miejski. Zielone ogrodowe dachy mają być odpowiedzią na intensywną zabudowę oraz na rosnące problemy ekologiczne w mieście (Tokarska i Osyczka, 2011). Z tego względu, w niektórych miastach, wprowadzane są programy i systemy zachęt ekonomicznych, jak ulgi lub zwolnienia od podatków oraz system dofinansowań inwestycji realizujących intensywne zielone dachy. Pierwszym miastem Ameryki Północnej, które wprowadziło program dotacji zielonych dachów było Chicago. Publikowane są materiały promujące i opisujące inwestycje (np. Chicago Green Roofs Guide for Building Green Roofs in Chicago); w Nowym Yorku wprowadzono program New York Green Roofs, w celu rozwiązania problemu wód opadowych poprzez infiltracje przez zieloną infrastrukture na dachach. W 2009 roku w Toronto wprowadzono regulacje prawne dotyczace sposobu zarządzania zielonymi dachami oraz kierowania ich budowa (Toronto Green Roof Bylaw), a w 2015 roku przyjęty został projekt Green Roof for Healthy Cities (zielony dach dla zdrowych miast). Ustawa ta nakazuje deweloperom, by pokrycie każdego nowego budynku składało się w co najmniej $50 \% \mathrm{z}$ zieleni. We Francji w 2015 roku wprowadzono ustawę, która ustala zasady pokrycia zielenią lub panelami słonecznymi dachów nowo wybudowanych nieruchomości komercyjnych. W Polsce, we Wrocławiu, w 2015 roku rada miejska przyjęła uchwałę, zgodnie z którą zwolniono od podatku od nieruchomości powierzchnie użytkowe lokali mieszkalnych znajdujące się w budynkach, w których w trakcie obowiązywania uchwały wykonane zostały zielone dachy, czy zainstalowane zostały na ścianach zewnętrznych ogrody wertykalne o powierzchni nasadzeń roślinnych nie mniejszej niż $15 \mathrm{~m}^{2}$ (Uchwała XV/268/15 Rady Miejskiej Wrocławia). W uchwale wskazano na realizację intensywnych zielonych dachów, stosując zapisy, że zielony ogród na dachu miał być wielowarstwowy, rośliny powinny być wieloletnie, a warstwa wegetacyjna nie może być mniejsza niż $40 \mathrm{~cm}$. Jest to jeden z elementów polityki miejskiej Wrocławia na rzecz wprowadzania intensywnej zielonej infrastruktury w nowych inwestycjach w mieście.

Millenium Park w Chicago jest reprezentatywnym przykładem przestrzeni otwartej realizowanej jako zielony dach z programem zieleni miejskiej o funkcjach środowiskowych i społeczno-kulturowych (rys. 1). 


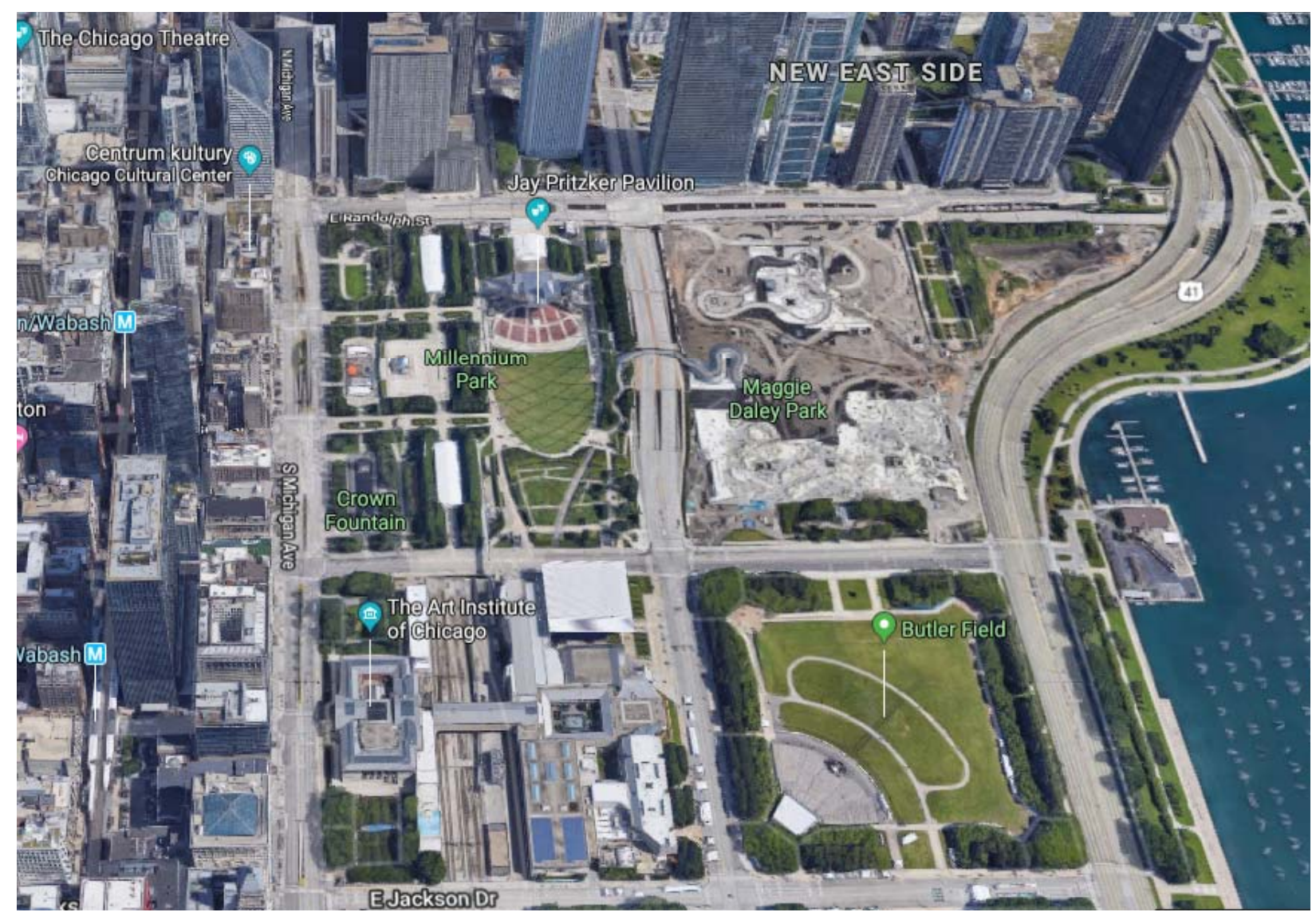

Rys. 1. Millenium Park w Chicago (https://www.google.com/maps, dostęp 15.09.2020)

Otwarty w 2004 roku park publiczny o powierzchni 9,9 ha jest uważany za największy projekt $\mathrm{z}$ zakresu zielonych dachów na świecie. Pod parkiem znajdują się dwa, wielopoziomowe parkingi na 4000 samochodów i stacja kolejowa. Na terenie parku wydzielono cztery strefy artystyczne: Jay Pritzker Pavilion z rozległą murawą zaprojektowany przez Gehry'ego (dom orkiestry symfonicznej, chóru, miejsce spotkań artystycznych, koncertów, występów), Cloud Gate (Wrota Chmur, tzw. fasolka Kapoora), Crown Fountain projektu artysty Plensa oraz pracowni Krueck and Sexton Architects (multimedialna fontanna w formie dwóch szklanych prostopadłościanów $\mathrm{z}$ wyświetlanymi na ich płaszczyznach twarzami mieszkańców Chicago), a także Lurie Garden (edukacyjny ogród powstały w kooperacji pracowni Kathryn Gustafson oraz Pieta Oudolfa).
Millenium Park jest przykładem realizacji zieleni, integracji społecznej oraz realizacji usług ekosystemowych w Lurie Garden. W Chicago w latach 2000-2001 na dachu ratusza założono intensywny ogród ekologiczny zaprojektowany przez McDonough'a, na potrzeby badania efektywności ogrodu w aspekcie minimalizowania efektów wyspy ciepła, jak i zwiększania zasobów bioróżnorodności. Na powierzchni $1886 \mathrm{~m}^{2}$ dachu, na 40-centymetrowej warstwie substratu posadzono 20000 roślin zielnych, 100 gatunków krzewów, 40 gatunków i odmian roślin pnących, oraz dwa gatunki i odmiany małych drzew. $Z$ czasem na dachu ustawiono kilka uli. Realizując zielone dachy w mieście, wprowadzane są również nowe funkcje produkcyjne - farmy miejskie stanowiące uprawę roślin użytkowych na potrzeby żywieniowe społeczności lokalnej oraz produkcję tlenu i biomasy. 


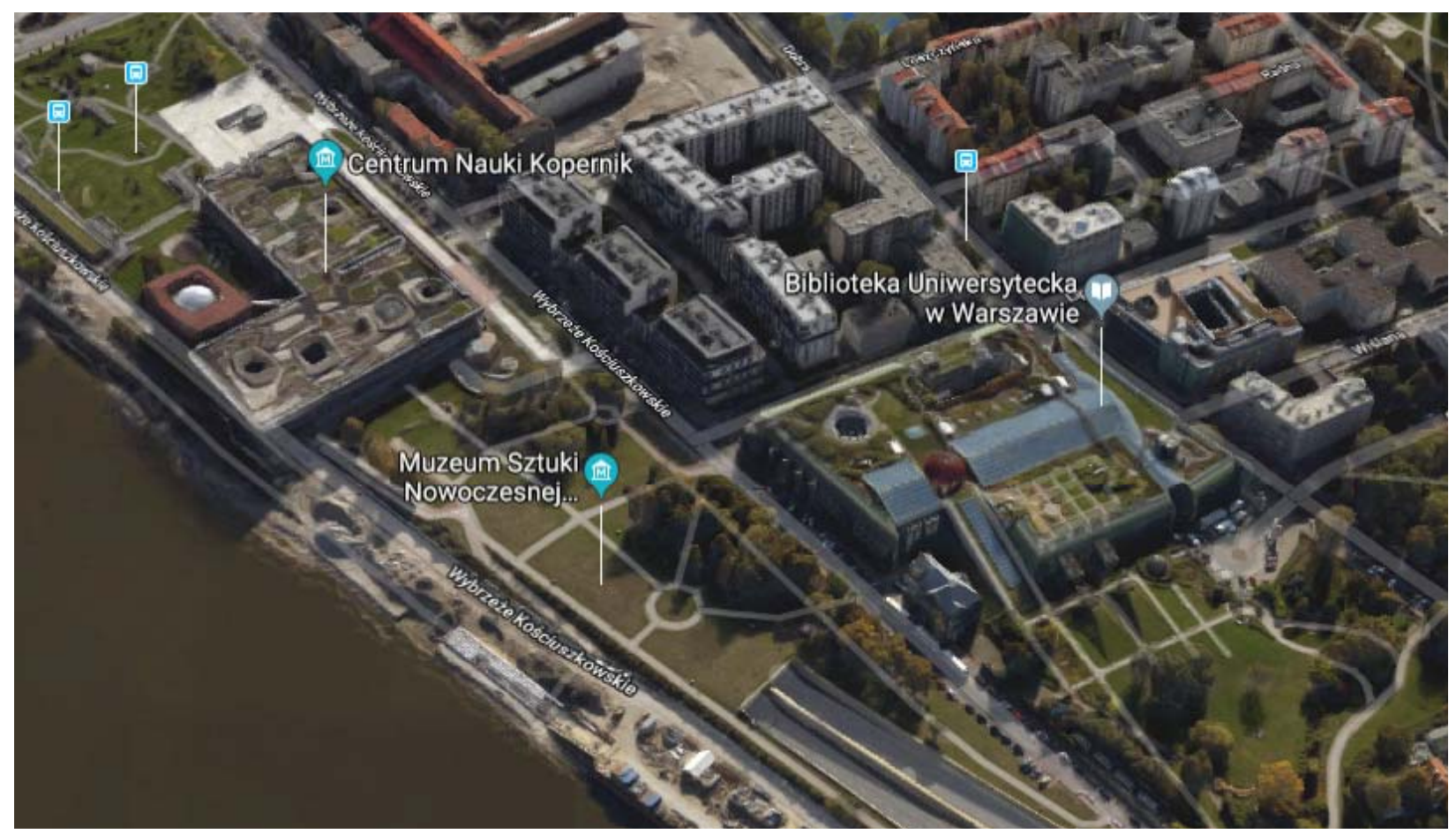

Rys. 2. Bulwary wiślane i Biblioteka Uniwersytetu Warszawskiego (https://www.google.com/maps, dostęp 15.09.2020)

Najbardziej znanym i publikowanym, bioróżnorodnym, intensywnym polskim zielonym dachem jest ogród na dachu Biblioteki Uniwersytetu Warszawskiego (Tokarska i Osyczka, 2011). Stanowi wielofunkcyjną przestrzeń otwartą powiązaną funkcjonalnie i krajobrazowo $\mathrm{z}$ terenami bulwarów wiślanych realizowanych $\mathrm{w}$ większości na płycie tunelu nad komunikacją drogową prowadzoną wzdłuż rzeki Wisły. Bulwary wiślane w Warszawie stanowią kolejny przykład zielonego dachu, jako otwartych przestrzeni publicznych z zielenią, małą architekturą i wyposażeniem dla sportu i rekreacji powiązane $\mathrm{z}$ Wisłą i biotopem rzeki (rys. 2). W przytaczanych przykładach zastosowano zielone dachy i ogrody wertykalne, a program inwestycji zawiera wiele elementów $\mathrm{z}$ modelu projektowania regeneratywnego.

\section{PROJEKTOWANIE REGENERATYWNE W KSZTAŁTOWANIU WSPÓŁCZESNYCH MIAST}

Regeneratywne projektowanie jest rozwinięciem idei Smart City i Eco City (Bibri i Krogstie, 2020) powiązane $\mathrm{z}$ kształtowaniem dynamiki ekosystemów, gospodarowaniem zasobami oraz przepływem energii i materii na terenach zurbanizowanych. Podstawowym założeniem $\mathrm{w}$ projektowaniu regeneratywnym jest dążenie do uzyskania samowystarczalności oraz zdolności regeneracyjnych jednostek urbanistycznych. Projektując tereny otwarte, zapewnić należy zdolności odnawiania oraz kształtowania odporności na zmiany klimatyczne, środowiskowe i funkcjonalno-przestrzenne realizowane w celu podniesienia wydajności usług przyrodniczych i społecznych. W modelu regeneratywnym proponowane jest stosowanie analiz, w celu optymalizowania wdrażanych rozwiązań w kontekście wydajności i efektywności powstałych struktur „inteligentnych sieci”, systemów powiązań przyrodniczych, społecznych i kompozycyjnych krajobrazu miejskiego.

Projektując przestrzenie otwarte w mieście, należy przeprowadzić wielokryterialną analizę w celu optymalizacji działań przestrzennych oraz programowania funkcji społecznych i ekosystemowych zgodnie z prognozowanymi kierunkami rozwoju systemu przyrodniczego miasta. Zapewniając zdolność adaptacji do zmieniających się czynników i 
uwarunkowań środowiskowych, gospodarczych, przestrzennych i społecznych. Analiza możliwości adaptacyjnych powinna opierać się na rozpoznaniu czynników wpływających na przekształcenia infrastruktury miejskiej, zabudowy i systemów miejskich, takich jak: system przyrodniczy (w tym terenów biologicznie czynnych, zielonej i błękitnej infrastruktury) (Solarek, Ryńska i Mirecka, 2016), zarządzanie i gospodarowanie lokalnymi zasobami, system przestrzeni publicznych, system mobilności w odniesieniu do struktury funkcjonalno-przestrzennej w krajobrazie miejskim. Kształtowanie wydajnych środowiskowo terenów otwartych powinno zostać odniesione do modelowych wzorców ,reakcji”, czyli scenariuszy opartych na optymalizacji działań i analizie efektywności zastosowanych środków oraz potrzeb ekosystemowych, przestrzennych i społecznych $\mathrm{w}$ adaptowanej strukturze miasta.

\section{PODSUMOWANIE I WNIOSKI}

Z przeprowadzonych badań wynika, iż proponowane rozwiązania zgodne $\mathrm{z}$ zasadami projektowania regeneratywnego powinny uwzględniać dbałość o bioróżnorodność oraz integrację zabudowy, przestrzeni miejskich z zieloną i błękitną infrastruktura.

Wdrażanie nowych funkcji w system przyrodniczy miasta, jak np. uprawy miejskie i produkcja biomasy czy zintegrowane gospodarowanie wodami, a więc rozszerzanie roli zielonej i błękitnej infrastruktury, będzie wymagać na nowo określenia standardów odnoszących się do współczesnych wyzwań ochrony i regeneracji ekosystemów miejskich.

W podsumowaniu pracy badawczej określone zostały nowoczesne zasady projektowania regeneratywnego, odnosząc je do kształtowania terenów w mieście:

- Kształtowanie regeneratywne rozwoju adaptowanych terenów zurbanizowanych warunkuje opracowanie nowych wskaźników urbanistycznych określających sposób zagospodarowania terenu odnoszące się do zabudowy oraz do elementów systemu przyrodniczego miasta.

- Nowe wskaźniki urbanistyczne i wytyczne planistycznych powinny definiować parametry i wydajność powierzchni biologicznie czynnych, wpływa- jących na jakość środowiska miejskiego i systemu przyrodniczego oraz strukturę funkcjonalno-przestrzenną i społeczną w mieście. Powinny odnosić się do intensywności i wydajności środowiskowej terenów i powierzchni biologicznie czynnych realizowanych na gruncie oraz na dachach i elewacjach budynków, kubaturowych obiektów inżynieryjnych i infrastruktury drogowej.

- Programowanie struktury funkcjonalno-przestrzennej zielonej i błękitnej infrastruktury określać powinno zadania i charakter zieleni w kontekście kształtowania parametrów środowiska (temperatury i wilgotności), retencji wody, oczyszczania powietrza, przewietrzania, produkcji tlenu oraz potrzeb użytkowych i produkcyjnych dla społeczności lokalnej.

- Określając przeznaczenie terenów zieleni oraz powierzchni biologicznie czynnych, należy uwzględniać funkcje produkcyjne farm miejskich (produkcja pożywienia) i algowych (produkcja biomasy i tlenu).

- W miejscowych planach zagospodarowania przestrzennego wskazane jest wprowadzanie lokalizacji intensywnych zielonych dachów.

Wyniki badań potwierdzają założenia badawcze, udowadniając, że idea regeneratywnego kształtowania terenów otwartych w mieście określa integracje usług dla społeczności lokalnej z usługami ekosystemowymi powierzchni biologicznie czynnych zielonej i błękitnej infrastruktury. Rekomenduje się stosowanie dodatkowych zapisów planistycznych dla terenów i zabudowy użyteczności publicznej, wskazując na konieczność wykonania powierzchni biologicznie czynnych i produkcji biomasy na terenie oraz jako zielone dachy lub elewacje. Wykazano, że rozwój współczesnych idei kształtowania zrównoważonego miasta prowadzi do redefiniowania terenów otwartych w strukturze funkcjonalno-przestrzennej i systemie przyrodniczym miasta. Wdrażanie współczesnych idei urbanistycznych, technologii wyposażenia przestrzeni miejskiej, powinno być realizowane w sposób umożliwiający regenerację systemu przyrodniczego i optymalne zarządzanie zasobami. Regeneratywny model projektowania wskazuje na symbiozę i integrację zabudowy, przestrzeni miejskich i powierzchni biologicznie czynnych, umożliwiając decentralizację 
produkcji żywności i energii, filtrację i oczyszczanie wody, absorpcję zanieczyszczeń powietrza i wytwarzanie tlenu. Prawidłowe określenie potrzeb przestrzennych, społecznych i środowiskowych umożliwi optymalizację i wdrażanie rozwiązań przestrzennych dla procesów ekosystemowych. Projektowanie regeneratywne realizowane jest na podstawie zintegrowanego projektowania i zarządzenia przez interdyscyplinarne zespoły w mieście.

\section{PIŚMIENNICTWO}

Bibri, S. E. i Krogstie, J. (2020). Smart Eco-City Strategies and Solutions for Sustainability: The Cases of Royal Seaport, Stockholm, and Western Harbor, Malmö, Sweden. Urban Science, 4 (1), 11.

Chicago Green Roofs Guide for Building Green Roofs in Chicago. Pobrano z lokalizacji: http://www.artic. edu/webspaces/greeninitiatives/greenroofs/main_map. $\mathrm{htm} /$ [dostęp 28.06.2014].

Cohen, B. (2015). The 3 Generations Of Smart Cities. Inside the development of the technology driven city. Pobrano z lokalizacji: https://www.fastcompany.com/3047795/ the-3-generations-of-smart-cities [dostęp 15.09.2020].

Degórska, B. (2004). Planowanie terenów otwartych w nowej przestrzeni miejskiej (na przykładzie strefy podmiejskiej Warszawy). W M. Kistowski (red.), Studia ekologiczno-krajobrazowe $w$ programowaniu rozwoju zrównoważonego. Przegląd polskich doświadczeń u progu integracji z Unia Europejska (strony 141-148). Warszawa: Polska Agencja Ekologii Krajobrazu.

DeKay, M. (2011). Integral Sustainable Design: Transformative Perspectives. New York: Routledge.

The Earth Charter (2000). New York: Earth Charter Associates.

Green City Programme (2016). Pobrano z lokalizacji: https://www.ebrd.com/documents/technical-cooporation/green-city-action-plan-in-tirana.pdf [dostęp 15.09.2020].

Joss, S. (2011). Eco-Cities: The mainstreaming of Urban Sustainability - key characteristics and driving factors. International Journal of Sustainable Development and Planning, 6 (3), 268-285.

Joss, S. Tomozeiu, D. i Cowley, R. (2011). Eco-Cities a global survey: eco-city profiles. London: University of Westminster.

Kwiecińska, K. i Szałata, Ł. (2012). Zielone dachy elementem zielonych miast. W M. Kosmala (red.), Zieleń a klimat społeczny miasta (strony 197-209). Torun:
Polskie Zrzeszenie Inżynierów i Techników Sanitarnych.

Lyle, J. T. (1994). Regenerative design for sustainable development. Hoboken: John Wiley \& Sons.

Mang, P. i Reed, B. (2012). Regenerative Development and Design: A Framework for Evolving Sustainability. New York: Wiley.

McLaren, D. i Agyeman, J. (2015). Sharing Cities: A Case for Truly Smart and Sustainable Cities. Cambridge: MIT Press.

Rapoport, E. i Vernay, A.-L. (2011). Defining the Eco-City: a Discursive Approach, Management and Innovation for a Sustainable Built Environment. Delft: Delft University of Technology.

Register, R. (2002). EcoCities: Building cities in balance with nature. Berkeley: Berkeley Hills Books.

Revision of the World Urbanization Prospects (2018). Pobrano z lokalizacji: https://population.un.org/wup/Publications/Files/WUP2018-Report.pdf [dostęp 15.09.2020].

Rights of Nature Tribunal (2017). Bonn: The Global Alliance for the Rights of Nature.

Roseland, M. (1997). Eco-City Dimensions: Healthy Communities, Healthy Planet. Gabriola, Island, BC, Canada: New Society Publishers.

Ryńska, E. D. (2012). Zintegrowany proces projektowania pro środowiskowego projektant a środowisko. Warszawa:Oficyna Wydawnicza Politechniki Warszawskiej.

Solarek. K., Ryńska, E. D. i Mirecka, M. (2016). Urbanistyka $i$ architektura $w$ zintegrowanym gospodarowaniu wodami. Warszawa: Oficyna Wydawnicza Politechniki Warszawskiej.

Świątek, L. (2016). Biokultura - inżynieria ekologiczna $\mathrm{w}$ projektowaniu regeneratywnym. W M. Banach i A. Januchta-Szostak (red.), Zrównoważone miasto - idee i realia (strony 27-36). Poznań: Wydawnictwo Politechniki Poznańskiej.

Tokarska, A. i Osyczka, D. (2011). Zielone dachy, jako odpowiedź na intensywną zabudowę miast. Zeszyty Naukowe. Inżynieria Środowiska / Uniwersytet Zielonogórski, 143 (23), 6-18.

Toronto Green Roof Bylaw (2009). Pobrano z lokalizacji: https://www.toronto.ca/city-government/planning-development/official-plan-guidelines/green-roofs/greenroof-bylaw/ [dostęp 15.09.2020].

Universal Declaration of Rights of Mather Earth (2010). Cochabamba: People's Conference on Climate Change and the Rights of Mother Earth, The Global Alliance for the Rights of Nature.

Uchwała nr XV/268/15 Rady Miejskiej Wrocławia z dnia 3 września 2015 r. w sprawie zwolnień od podatku od 
nieruchomości powierzchni użytkowych lokali mieszkalnych w ramach projektu intensyfikacji powstawania terenów zieleni w obrębie Miasta Wrocławia. Dz. Urz. Woj. Dolno. z 15.09.2015 r., poz. 3763. Pobrano z lokalizacji: http://g.ekspert.infor.pl/p/_dane/akty_pdf/ U70/2015/175/3763.pdf\#zoom=90 [dostęp 15.09.2020].
Van de Ryn, S. (2014). Culture, Architecture and Nature: An Ecological Design Retrospective. New York: Routledge.

Wahl, D. Ch. (2016). Designing Regenerative Cultures. Chicago: Triarchy Press.

World Charter for Nature (1982). New York: United Nations.

\section{PROBLEMS OF REGENERATIVE DESIGN IN THE CITY}

\section{ABSTRACT}

Shaping open areas in the functional and spatial structure of a city is the subject of research and analyses aimed at determining the quality of life and environmental parameters in a city and formulating conclusions regarding the spatial development planning and city landscape. The study points to problems with the transformation of open areas in a city. The urban ecosystem regeneration is linked with the urban environment parameters and social integration improvement. The modern urban design is based on a functional structure forming an inseparable whole with the natural system, including green and blue infrastructure. The analysis of contemporary models of shaping open spaces in cities indicates that the principles of regenerative design are applied. The regenerative design of open areas leads to the development of guidelines specifying new standards for shaping the functional and spatial structure related to the natural system of a city. Contemporary spatial planning should take into account the functional and qualitative parameters as well as the effectiveness of green areas. The implementation should be optimized in connection with the services contributing to the integration of the local community.

Key words: open areas, regenerative design, functional and spatial structure of a city, urban green system, green and blue infrastructure 